\title{
Pendampingan Pembelajaran Online di Masa Pandemi Covid-19 pada Siswa dan Siswi MA Al-Jufri
}

\author{
Jaftiyatur Rohaniyah ${ }^{1}$, Ainullah², Fitrah Yuliawati ${ }^{3}$, Linta Wafdan Hidayah ${ }^{4}$ El \\ Indahnia Kamariyah ${ }^{5}$
}

Universitas Islam Madura, Pamekasan 1,3,4,5

Sekolah Tinggi Agama Islam Miftahul Ulum, Pamekasan²

\{javetien8@gmail.com¹, ainullah261086@gmail.com², fitrahyuliawati@gmail.com³ , missalindan@gmail.com ${ }^{4}$ , elindahniak@gmail.com $\left.{ }^{5}\right\}$

Keywords: Online Studying, Covid-19

Katakunci:

Pembelajaran Online, Covid-19

\begin{abstract}
Online learning during a pandemic is often an obstacle for students, both elementary, junior high and high school students. This is due to limited tools and limited knowledge on the platforms used in online learning. As experienced by students of MA Al-Jufri in Blumbungan, Pamekasan Regency. Problems that often arise in the implementation of online learning include: the limitations of students in owning an Android smartphone, insights in carrying out access to online learning through a platform designated by the school. From these problems, it is necessary to provide assistance to students at MA Al-Jufri on how to run features on several platforms that can be used in online learning. Like zoom, google meet, blog and google form. Therefore, this community service is carried out to provide assistance for MA Al-Jufri students to provide scientific and mental readiness in online learning during the Covid-19 pandemic. The methodes used include: preparation, implementation and closure. In the preparation stage, the community service team first collaborated with the school in carrying out this service, then this was followed by the implementation of this service which was carried out on February 2, 2021 in the male and female classrooms. Furthermore, the last method is closing. The implementation team closed the dedication by proving the results of the dedication in the form of blog work and the zoom operation process. So that the closing is also the final conclusion / result of this form of service.
\end{abstract}

\footnotetext{
Abstrak. Pembelajaran online pada masa pandemic seringkali menjadi kendala pada siswa baik siswa SD, SMP dan SMA. Hal ini disebabkan oleh keterbatasan alat dan keterbatasan pengetahuan pada platform yang dipakai dalam pembelajaran online. Seperti yang dialami oleh siswa dan siswi MA Al-Jufri di Blumbungan Kabupaten Pamekasan. Masalah yang seringkali mungcul dalam pelaksanaan pembelajaran online antara lain: keterbatasan siswa dalam memiliki smartphone android, wawasan dalam menjalankan akses pembelajaran online melalui platform yang ditunjuk sekolah. Dari masalah tersebut, perlu diadakan pendampingan pada siswa dan siswi di MA Al-Jufri tentang tatacara menjalankan fitur dalam beberapa platform yang bisa digunakan dalam pembelajaran online. Seperti zoom, google meet, blog dan google form. Maka dari itulah, tujuan dari pengabdian masyarakat ini
} 
dilakukan untuk memberikan pendampingan bagi siswa dan siswi MA Al-Jufri untuk memberikan kesiapan ilmu dan mental dalam belajar online di masa pandemi covid-19. Metode dalam pengabdian ini antara lain: persiapan, pelaksanaan dan penutupan. Dalam tahap persiapan, tim pengabdian masyarakat terlebih dahulu melakukan kerjasama dengan pihak sekolah dalam melaksanakan pengabdian ini, selanjutnya disusul dengan pelaksanaan pengabdian yang di lakukan pada tanggal 12 Januari 2021 di ruang kelas putra dan putri. Selanjutnya metode terakhir yaitu penutup. Tim pelaksana melakukan penutupan pengabdian dengan membuktikan hasil pengabdian berupa karya blog dan proses pengoprasian zoom. Sehingga dalam penutupan tersebut juga menjadi kesimpulan akhir / hasil dari bentuk pengabdian tersebut.

\section{Pendahuluan}

Era Society 5.0 ditandai dengan penerapan teknologi digital ke berbagai aktivitas manusia. Pandemi Covid-19 mengharuskan hampir seluruh aktivitas manusia beralih ke media digital, termasuk layanan pendidikan. Kini, layanan pendidikan harus beradaptasi dengan metode pembelajaran online. Pembelajaran online perlu dilakukan dan disosialisasikan pada siswa agar bias melakukan mandiri belajar dan dapat mengurangi peningkatan penyebaran resiko covid-19 di lingkungan sekolah. Perubahan ini menjadi tantangan bagi pendidikan Indonesia yang juga harus mempersiapkan peserta didik untuk beradaptasi menghadapi tantangan era Society 5.0. Pengabdian ini bertujuan untuk memberikan informasi tentang tata cara dan proses pembelajaran online selama studi dari rumah selama pandemi Covid-19. Pengabdian ini dilakukan pada siswa MA Al-Jufri yang terletak di Desa Blumbungan. Ada beberapa masalah yang di hadapi oleh siswa dan siswi di MA Al-Jufri dalam melaksanakan pembelajaran daring / online antara lain: 1. Kesulitan dalam menggunakan aplikasi zoom. 2. Kesulitan dalam memenuhi tugas yang diberikan oleh guru lewat google classroom. 3. Kesulitan dan keterbatasan pengetahuan dalam membuat blog guna menjadi sarana dalam pengumpulan tugas sekolah. Sehingga, melihat permasalahan tersebut. Beberapa masalah tersebut harus segera diatasi lewat sosialisasi ataupun pendampingan belajaran online. Hal ini dilakukan untuk memberikan kesiapan dan pengetahuan terkait proses pembelajaran secara online selama masa pandemi covid 19. Menurut Veronika (Vol.54, No.1: 2021) menyatakan bahwa "The success of online learning was highly dependent on several integrated components, such as students, educators, learning resources, and the technology used" bahwa kesuksesan dalam pembelajaran online bergantung pada beberapa komponen yang terintegrasi seperti, siswa, pendidik, sumber dan bahan pembelajaran dan juga teknologi yang dipakai. Maka dari itu pengabdian ini dilakukan untuk memberikan kesiapan bagi para pendidik dan siswa di sekolah tersebut dalam menjalankan pembelajaran online selama masa covid-19. Tim 
pelaksana pengabdian memilih sekolah Al-Jufri karena selain siswa-siswi disekolah tersebut mengalami banyak permasalahan dalam pembelajaran online, Sosialisasi ini dilakukan karena sekolah tersebut merupakan sekolah unggul yang harus siap melaksanakan pembelajaran online selama masa covid.

\section{Metode}

Metode pengabdian ini dilakukan dengan cara sosialisasi pada siswa secara langsung dalam memberikan pendampingan tentang tata cara menjalankan fitur platform pembelajaran online antara lain: google classroom, google meet, blog, google form, zoom dan WAG (whatsapp Group). Sosialisasi tersebut dilakukan secara bertahap pada tanggal 12 Januari 2021 sampai 14 Januari 2021. Tahapan pelaksanaan pengabdian ini Antara lain:

\section{Tahap 1 : Persiapan}

\section{Tahap 2: Pelaksanaan}

\section{Tahap 3: Penutupan}

\section{Tahap 1: Persiapan}

Dalam tahap persiapan, Tim pengabdian masyarakat melakukan pemberitahuan pada pihak sekolah dan pemberian surat tugas tentang pelaksanaan pendampingan pembelajaran online pada siswa dan siswi MA Al-Jufri di Desa Blumbungan. Hal ini dilakukan 1 minggu sebelum pelaksanaan pengabdian

\section{Tahap 2: Pelaksanaan / Implementasi}

Dalam tahap pelaksanaan, pendampingan pembelajaran online dilakukan di lingkungan sekolah setelah siswa melakukan ujian UTS yaitu pada tanggal 12-13 Januari 2021. Pelaksanaan tersebut dilakukan agar fasilitas dalam proses pendampingan pembelajaran online bias terpenuhi seperti pemakaian laptop sekolah yang bias dipakai oleh siswa dalam pendampingan. Pendampingan belajar online ini di bagi 2 sesi. Sesi 1 untuk pendampingan belajar pada siswa putra dan sesi 2 dilakukan pendampingan belajar pada siswi putri. 
Gambar 1: Pendampingan belajar online pada siswa / putra

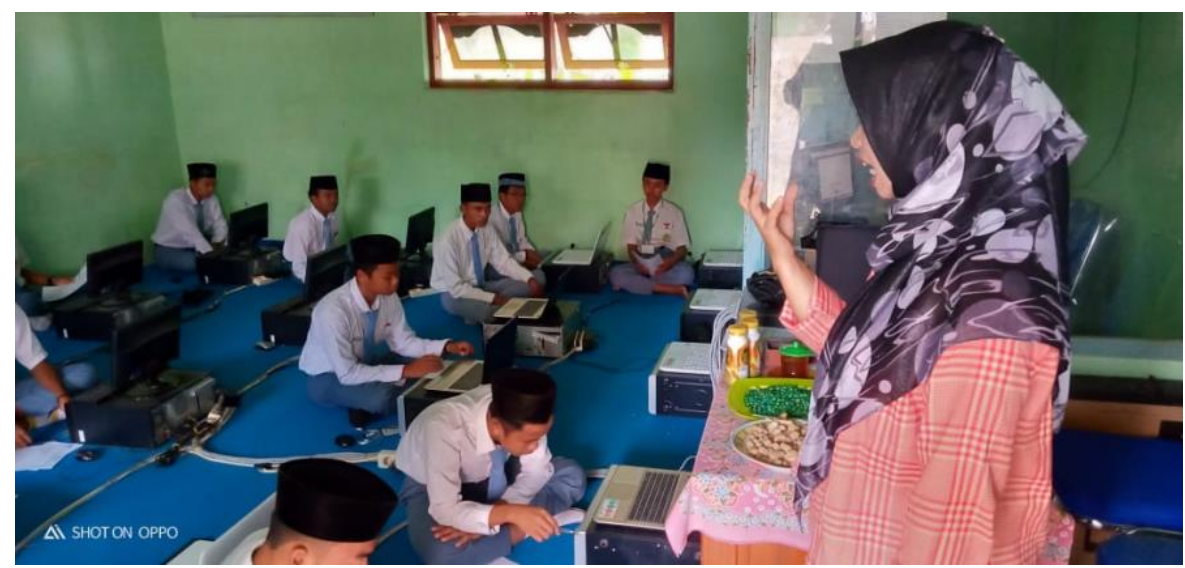

Gambar 2: Pendampingan belajar online pada siswi / putri

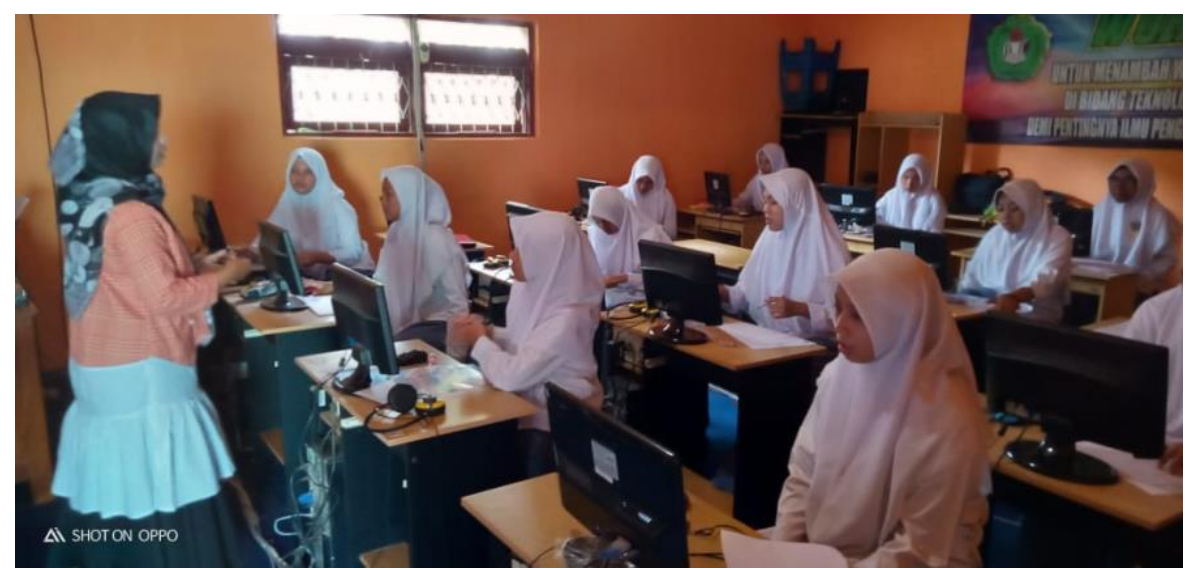

Tahap 3: Penutupan

Pada tahap penutupan, yaitu tanggal 14 Januari 2021, tim pengabdian masyarakat meminta siswa untuk mengimplementasikan hasil dari yang telah dipelajari selama pendampingan seperti meminta siswa untuk membuat sebuah blog dan mengisi google form yang sudah disediakan oleh tim serta berpraktek dalam menjalankan fitur zoom dan WAG.

Gambar 3: Siswa berlatih membuat blog dan menjalankan fitur zoom 


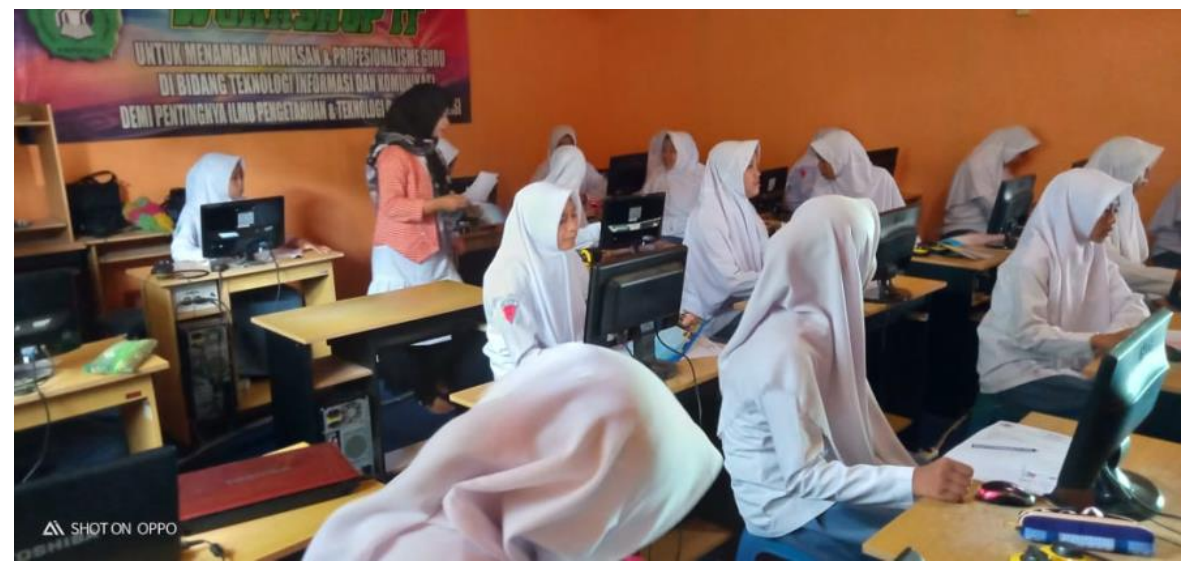

\section{Hasil}

Dari hasil pengabdian ini, siswa mampu menjalankan fitur blog, google classroom, zoom dan WAG serta dapat membuat sebuah blog dan mengisi google form. Dengan demikian, siswa memiliki kesiapan pengetahuan dalam menjalankan pembelajaran online selama masa covid 19.

\section{Pembahasan}

Dari hasil pengabdian ini, siswa dan siswi MA Al-Jufri mendapatkan beberapa pengetahuan tentang proses pembelajaran online seperti google classroom, zoom dan platform lain. Menurut Unik (Vol.2, No.2: 2020) mengatakan bahwa Google Classroom digunakan oleh setiap orang dari ruang lingkup/ jenjang pendidikan yang berbedabeda baik dari tingkat SD, SMP, SMA/SMK maupun Perguruan Tinggi. Di samping mudah di dalam menggunakannya Google Classroom juga sangat efisien dan tidak terlalu rumit pada saat kita akan mengakses dan menggunakannya untuk melakukan pembelajaran yang diberikan oleh guru.

Sedangkan Zoom merupakan aplikasi komunikasi dengan menggunakan video sehingga pada saat digunakan untuk proses pembelajaran maka kita akan merasa bahwa kita sedang tatap muka secara langsung karena kita mampu melihat orang yang jauh dengan menyalakan camera yang kita miliki didalam menggunakan platform zoom ini (Astini, 2020).

Dari hasil pengabdian ini, siswa dan siswi mendapat pemahaman dalam log in dan mengoprasikan layar zoom termasuk mute / unmute juga vitur lainnya seperti menerapkan background dalam video dan mengunggah materi di layar screen. Pemanfaatan video conference pada pembelajaran jarak jauh akan sangat membantu siswa dan siswi dalam belajar karena pendidik dapat berinteraksi walaupun ditempat yang berbeda. Untuk merangsang semua aspek perkembangan pada siswa tidak lepas dari media pembelajaran, hal ini dikarenakan mahasiswa 
belajar dilakukan menggunakan media pembelajaran yang nyata, dan dengan media pembelajaran ini mahasiswa dapat berjalan secara efektif (Firman: 2020).

Manfaat dalam menggunakan zoom ini antara lain: bisa menampung banyak participant atau murid dalam melakukan pembelajaran, mendukung dalam pelaksanaan presentasi dan materi yang di berikan oleh guru, menggunakan video dan suara yang jelas dalam pembelajaran online. Hal ini juga di support oleh Junita (Vol.IX, No.2: 2020) mengatakan bahwa Zoom dapat dikatergorikan sebagai media pembelajaran online yang dapat diartikan sebagai suatu jenis belajar mengajar yang memungkinkan tersampaikannya bahan ajar ke siswa dengan menggunakan media Internet. Media pembelajaran online sebagai sebuah alternatif pembelajaran yang berbasis elektronik memberikan banyak manfaat terutama terhadap proses pendidikan yang dilakukan dengan jarak jauh. Sedangkan menurut

Google Classroom merupakan sebuah platform pembelajaran online yang dapat digunakan oleh guru maupun murid. Platform ini dapat memudahkan guru dalam memberikan soal tugas maupun soal ujian kepada siswa dan siswa bisa mengerjakan dan mengirim tugas yang diberikan oleh guru. Dari hasil pengabdian ini, siswa dan siswi dilatih dan didampingi secara baik oleh tim pengabdian masyarakat untuk bisa mengakses google classroom. 80\% dari jumlah siswa dan siswi di MA Al-Jufri sudah bisa log-in melalui akun Gmail masing-masing. Sedangkan 20\% dari mereka masih belom memiliki akun gmail, sehingga perlu didampingi untuk pembuatan akun terlebih dahulu sampai semua siswa dan siswi bisa log-in melalui akun masingmasing. Setelah semua siswa log in, selanjutnya siswa diarahkan untuk bergabung pada kelas yang sudah dibuat oleh guru dan memasukkan kode yang sudah disediakan sampai pada tahap akhir dalam mengisi tautan atau link google classroom yang berisi tugas-tugas yang diberikan oleh guru.

Manfaat dari google classroom ini antara lain: Dapat digunakan sebagai wadah diskusi antara guru dan murid, guru dapat memberikan suatu topic materi dan siswa dapat memberikan pendapatnya melalui kolom komentar. Selain itu, murid juga dapat mengunduh materi yang dibagikan oleh guru dan dapat menyelesaikan tugas yang diberikan. Hal ini juga sesuai dengan pendapat Ima (2021) bahwa google classroom dapat membantu siswa dalam mengerjakan tugas dan dapat mengisi absensi setiap pembelajaran dimulai yang nantinya akan tersimpan di google drive dan tersusun rapi. Adapun menurut Shampa (2016) mengatakan bahwa google classroom dapat membantu dalam memantau pembelajaran siswa. Hal inilah yang menjadi alasan kenapa google classroom juga menjadi topic pembekalan pembelajaran daring bagi siswa dan siswi MA Al-Jufri.

Sedangkan WAG merupakan salah satu media komunikasi yang sudah tidak asing lagi ditelinga kita bahkan sangat populer sekali serta merupakan platform yang kita gunakan saat ini baik untuk kepentingan pribadi maupun sosial. Aplikasi yang satu ini, hampir dimiliki oleh semua pengguna gadget. Selain dapat digunakan untuk 
berkomunikasi dengan jarak jauh, platform ini juga bisa digunakan sebagai media penunjang pada proses pembelajaran seperti pada masa pandemi seperti sekarang ini. Platform ini merupakan alat yang digunakan untuk melakukan komunikasi jarak jauh berupa percakapan baik menggunakan tulisan, gambar, suara maupun video. WhatsApp mampu terhubung dengan teman serta keluarga kita yang ada dimanapun dan kapanpun ketika kita memiliki jaringan yang baik yang mampu menjadi pendukung untuk kita mengaksesnya (Roida, 2020).

Dari hasil pengabdian ini, WAG juga menjadi materi penting bagi siswa dan siswi MA Al=jufri. Selain untuk menfungsikan layanan WhatsApp, siswa juga dipermudah dalam pembelajaran online dari rumah masing-masing. Disini, siswa dapat secara mandiri belajar melalui komunitas / grup yang sudah dibuat dalam WhatApp. Guru maupun murida bisa secara mudah membagikan materi baik dengan mengirimkan file, pesan suara maupun mengirim video tentang materi yang dipelajari. Dan hasil dari pengabdian ini menggambarkan bahwa WAG merupakan cara paling praktis dan paling mudah digunakan oleh siswa-siswi MA Al-Jufri. Rata-rata dari mereka dapat menjalankan fitur WAG dengan baik dan tanpa kendala.

\section{Kesimpulan}

Dari hasil pendampingan ini, siswa dan siswi sudah bisa menjalankan 3 fitur-fitur dari 3 platform pembelajaran online, antara lain: blog, google classroom, dan WAG dengan baik. Sehingga siswa dan siswa memiliki kesiapan pengetahuan dalam melaksanakan pembelajaran daring atau online

\section{Pengakuan}

Kami Ucapkan terimakasih kepada Kepala MA Al-Jufri di Desa Blumbungan yang sudah memberikan ijin pada kami sebagai tim pelaksana pengabdian masyarakat dengan judul "Pendampingan Pembelajaran Online di Masa Pandemi Covid-19 pada siswa dan Siswi MA Al-Jufri"

\section{Referensi}

Astini, N. K. (2020). Tantangan dan Peluang Pemanfaatan Teknologi Informasi dalam Pembelajaran Online Masa Covid-19. Jurnal IImu Pendidikan, 3(2), 241255

Firman, (2020). Pembelajaran Online Ditengah Pandemic Covid-19. Indonesian Journal of Educational Science Volume 02, No 02 Maret 2020, 82 
Ifthkar, Shampa. (2016). Google Classroom: What Works and How?. Journal of Education and Social Sciences. Vol.3

Ima Febrianti, (2021). Implemetasi Penggunaan Google Classroom pada Pembelajaran Daring Masa Pandemi Covid-19 di Kelas VI Sekolah Dasar, Universitas Jambi Press.

Junita Rofika., Dini, F (2020), Efektivitas Penggunaan Aplikasi Zoom Sebagai Media Pembelajaran Online Pada Mahasiswa Saat Pandemi Covid-19. Jurnal Communio : Jurnal IImu Komunikasi, Volume IX, No. 2, Juli - Desember 2020, hIm 1630 - 1640

Roida Pakpahan, Y. F. (2020). Analisa pemanfaatan Teknologi Informasi Dalam Pembelajaran Jarak Jauh di Tengah Pandemi Virus Covid19. Journal Of Information System, Applied, Management, Accounting and Research, 3233

Unik, H.S. (2020). Pemanfaatan Teknologi Media Pembelajaran di Masa Pandemi Covid-19. Jurnal Pendidikan Dasar. Vol.2 No.2 Desember 2020. p-ISSN 2685-7642 | e-ISSN 2685-8207

Veronika A. S, Yustinus B. H. (2021), Online Learning During the Covid-19 Pandemic (Study at Several Schools and University in Indonesia). Jurnal Pendidikan dan Pengajaran, Vol.54, No.1, e-ISSN: 2549-2608 